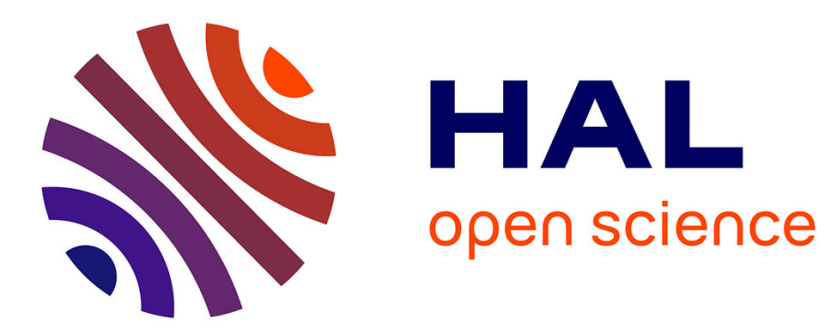

\title{
Secours Catholique
}

Edith Archambault

\section{To cite this version:}

Edith Archambault. Secours Catholique. List R., Anheier H., Toepler S. Editors, International Encyclopedia on Civil Society, 2d Edition,, pp.1 - 2, 2021, 10.1007/978-3-319-99675-2_456-1 . halshs03173241

\section{HAL Id: halshs-03173241 https://shs.hal.science/halshs-03173241}

Submitted on 18 Mar 2021

HAL is a multi-disciplinary open access archive for the deposit and dissemination of scientific research documents, whether they are published or not. The documents may come from teaching and research institutions in France or abroad, or from public or private research centers.
L'archive ouverte pluridisciplinaire HAL, est destinée au dépôt et à la diffusion de documents scientifiques de niveau recherche, publiés ou non, émanant des établissements d'enseignement et de recherche français ou étrangers, des laboratoires publics ou privés. 


\section{Secours Catholique}

Edith Archambault

Department of Economics, University of Paris1

Pantheon-Sorbonne, Paris, France

\section{Relevance}

Secours Catholique is the French organization of Caritas Internationalis and a confederation of Catholic relief, development, and social service organizations operating in France and in developing countries.

\section{Introduction}

Secours Catholique is a service of the Catholic Church in France. It refers to the social teaching of the Church. Its annual report on poverty in France is a main source of information on this issue.

\section{Brief History}

Secours Catholique was founded in 1946 as a declared association by a priest, Jean Rhodain, who was struck by the great poverty in France after World War II. Secours Catholique was dedicated to the alleviation of poverty and operated mainly by volunteers. In 1950, it joined the newly created confederation, Caritas Internationalis, and in 1962, it was acknowledged as a public utility association. Its international action expanded in the 1970s and 1980s.

In 1990, Secours Catholique created a subsidiary, Cités du Secours Catholique, whose mission is to welcome and accommodate, house, and accompany nearly 11,000 people a year, in a situation of social exclusion and/or disability, on the path of integration and autonomy.

In 2009, it was at the origin of Fondation Caritas, a public utility foundation with the same mission in France and in the world as Secours Catholique. In addition, Fondation Caritas allows families to create their own foundations. In 2019, about 100 family foundations are sheltered by the foundation that affords legal advice and financial management.

\section{Mission}

According to the bylaws, the mission of Secours Catholique is to expand Christian charity in France and in the world without any national or sectarian particularism and to afford relief, material, and moral help to the poor. Its key values are justice, solidarity, fraternity, and respect for human dignity. 


\section{Activities}

The activities are shared between France (2/3) and the Third World (1/3).

The main program is to help the poor in France by providing advice and in-kind and financial assistance to children and families. Secours Catholique runs social facilities and services to welcome the homeless and immigrants night and day. It also helps the unemployed to create their own enterprises in collaboration with Caritas Foundation. It affords emergency relief during times of natural disaster or social crisis, either alone or in partnership with public agencies and other nonprofit organizations. On refugees and immigrant issues, it works in cooperation with CIMADE, the main Protestant organization.

Every year about $1,400,000$ persons are benefited by Secours Catholique in France. In 2015, Secours Catholique created through Fondation Caritas an impact investment fund intended towards innovative charitable projects in France or Third World.

The international activities of Secours Catholique are mainly located in Africa first and then Asia, besides East Europe and Latin America. Emergency relief and assistance to refugee camps are operated with an aim of achieving sustainable development. The development programs are run through local organizations; they give priority to education and women's empowerment.

The major publication is the 600,000 edited copies of the monthly Messages, sent mainly to donors.

\section{Structure and Governance}

Secours Catholique is a confederation of 104 departmental organizations grouping 3,500 local teams. Volunteers are its main human resource: 68,000 volunteers work inside the local teams and their number is growing; however, 950 salaried employees are also included in the paid staff. The governance at the upper level is the responsibility of a board of 16 persons, chaired since 2014 for the first time by a woman, Véronique Fayet, a former politician.

\section{Funding}

The annual budget was $€ 135$ million in 2017 (plus the money value of volunteering: $€ 203$ million). The main financial resource through bequests and gifts comes to about $78 \%$ of the annual budget; public subsidies are less than $8 \%$. The net assets are $€ 155$ million.

\section{Major Contributions}

Secours Catholique is among the most popular charitable organizations and a masterpiece of the Catholic Church in France. Every year, it reports on extreme poverty in France and its evolution. This report gives interesting information to the media, the public at large, and even to the government. Through Fondation Caritas, Caritas Europa, Caritas Internationalis, and other networks, its contribution to the alleviation and the knowledge of poverty and social inequality is decisive.

\section{Cross-References}

- Caritas Internationalis

- Federations, Nonprofit

- Foundations, Family

$\checkmark$ Volunteers

\section{References}

Secours Catholique Rapport statistique 2017. 